\title{
Study of the Effect of Nanotechnology Drugs (MCS-B) on the Aggregation of Human Blood Platelets
}

\author{
Andrey N. Belousov* \\ Laboratory of Applied Nanotechnology of Belousov, Department Anesthesiology, Intensive Care, \\ Transfusiology and Hematology, Kharkov Medical Academy of Postgraduate Education, Ukraine \\ *Corresponding Author: Andrey N. Belousov, Laboratory of Applied Nanotechnology of Belousov, \\ Department Anesthesiology, Intensive Care, Transfusiology and Hematology, Kharkov Medical Academy of \\ Postgraduate Education,Ukraine. Email: an.belousov2012@ukr.net
}

\begin{abstract}
This scientific article is devoted to the study of the effect of magnetite nanoparticles (MCS-B brand) on the functional platelets activity of human. $0.9 \% \mathrm{NaCl}$ was used as a control. The results of the study showed that the use of $\mathrm{NaCl}$ saline solution shifts the colloidal suspension equilibrium of platelets towards a significant $(P<0.001)$ increase in the rate and index of their aggregation. For the first time, the effect of $0.9 \% \mathrm{NaCl}$ on function of platelets makes us reconsider the concept of safety of infusion solutions in patients with initial signs of platelet disorders hemostasis. On the contrary, the use of MCS-B nanoparticles significantly revealed $(P<0.05)$ an increase in the stability of colloidal suspension of platelets. This is an important pathogenetic factor which affects the occurrence of correction of hemostasis in conditions of blood clotting disorders.
\end{abstract}

Keywords: platelets, functional, MCS-B nanoparticles, saline solution, aggregation rate, aggregation index.

\section{INTRODUCTION}

Currently, one of the main problem that happens in the treatment by extracorporeal methods of hemosorption is systemic shifts in homeostasis. Among these complications the most significant are blood cells traumatization and hemorrhage [1]. Direct physical contact of blood with sorbent surface causes activation of a multistage reaction of thrombosis. Adhesion of platelets with a sorbent leads to damage of their morphological integrity. The result of which is entry into the blood of activators aggregation and comes platelets glue. The interaction of platelets with the surface of sorbents depends on the roughness, porosity, charge, chemical activity of sorbents and functional characteristics of platelets, their ability to aggregation and adhesion, which change with various diseases. As a result of hemosorption is reduced the amount of prothrombin, fibrinogen and platelets. Despite the fact that these indicators are restored a few days after the session of hemosorption and even exceed the initial levels, there is a real risk of hemorrhagic complications. Platelet adhesion occurs only to the damaged epithelium in contact with connective tissue mainly due to the formation of collagen. The mechanism of adhesion is associated with the Zeta potential of platelets: groups of negatively charged of sialic acids on their membrane react with negatively charged amino groups of vascular wall collagen. The release reaction is an active secretory process that proceeds without membrane damage and destroy of the cells. The release of ATP and other factors in the release reaction promotes platelet aggregation. Inhibit aggregation: elevated level of cAMP in platelets; prostaglandins $\mathrm{E}, \mathrm{D}$; prostacyclin [2]. Violation of platelet function leads to changes in hemostasis and the development of pathological conditions in the circulatory system.

Currently, methods of correction of hemostasis parameters remain one of the most relevant in clinical medicine. For example, currently the possibility of inhibition of platelet adhesion and aggregation is a cornerstone problem of modern cardiology [3]. Modern medicine has in its arsenal pharmacological drugs that can actively inhibit the function of platelets, but excessive oppression can lead to the loss of their protective action [2]. Hemosorbents used in medicine damage platelets.

Currently, new methods of hemosorption using non-traumatic sorbents are being actively developed. For example, until recently, a promising direction for the development of a 
new method of extracorporeal hemocorrection, in order to reduce the degree of damage to blood cells, was the attempt to use hemosorbents coated with albumin and other substances.

However, the use of sorbents coated with albumin has not found wide practical application in connection with the spread of viral hepatitis, HIV infection, increased allergization of patients.

Magnetic fields have one of the greatest effects on the circulatory system [4-7]. Therefore the next effective way to prevent the destruction of platelets is to conduct hemosorption in an alternating magnetic field. Studies were conducted on dogs with using activated carbon brand of AR-3 as a sorbent. It turned out that during the first 10 minutes, more than 2 times less platelets are destroyed than under normal conditions. In the next 20 minutes, the degree of platelet destruction increases, but remains significantly lower than without the use of a magnetic field [7].

The therapeutic effect of magnetic fields on animals and humans was proved by V. I. Drozdov in 1879. The greatest interest in magnetotherapy falls on the 70-80 - ies of XX century [8]. Positive therapeutic effect of magnetotherapy was observed in burn and mechanical trauma, osteochondrosis, dental, ophthalmological and infectious diseases, hypertension, as well as other pathologies [8-13]. There is evidence that the change in the geomagnetic field of the Earth leads to a deterioration of health in cardiovascular diseases, up to an increase in mortality in them [14-16]. More detailed studies have shown that variable and pulsed fields can induce local currents in electrically excitable tissues whose levels exceed natural ones. This effect is the basis for additional biological changes. The magneto mechanical effect can be manifested by the appearance in diamagnetic and paramagnetic molecules of torque, which orients them in such a way that a configuration is formed reduces their free energy in the field.

The development of a new direction in sciencenanotechnology in the field of medicine allows to improve methods of hemocorrection, to create a new class of biocompatible magnetically controlled sorbents combining sorption and magnetic effects in one substance. The use of magnetite nanoparticles as a hemosorbent completely exclude the possibility of mechanical traumatization of blood elements.
Each particle of magnetite is a subdomain of an elementary magnet that induces a constant magnetic field. The study of the General toxic effect of magnetite was carried out in an acute experiment on laboratory animals. Magnetite $\left(\mathrm{Fe}_{3} \mathrm{O}_{4}\right)$ was nontoxic in acute experiments [1719]. Wide introduction of nanotechnological preparations (magnetite nanoparticles) in clinical medicine allows to improve methods of extracorporeal hemocorrection and to outline fundamentally new approaches to solving problems of correction hemostasis [20].

In Ukraine, the first biocompatible magnetite nanoparticles for medical use were manufactured and patented by Andrey N. Belousov in 1998. These are intracorporeal nanobiocorrector (ICNB), magnet-controlled sorbent (MCS-B), and biologically active nanodevice (Micromage-B) [21-24].

It was found that magnetite nanoparticles regulated the activity of the enzyme link of the antioxidant system in red blood cells, effectively modulate metabolic processes in leukocytes in healthy and sick patients [25-27]. Previously the complex investigations were demonstrated that in whole standardized biocompatibility of magnetite nanoparticles have nonspecific and modulated effect on metabolic processes. Study of ultrastructure of the reticuloendothelial system (lungs, liver and kidneys) it was proved that after injection of biocompatibility magnetite nanoparticles caused nonspecific activation of the metabolic processes, increase potential of organelle cells and adaptive mechanisms, acceleration of reparative processes a level of macromolecules and membranes. [28-30]. Sorption and magnetic properties of magnetite nanoparticles not only allow selectively absorb the protein of surface membrane cells by (according to the principle of magnetophoresis) but also to prevent the oxidative modification of proteins by way of stabilizing the active groups, normalizing a state of receptors that are located on the surface membrane of cells, increasing activity of enzymes' membrane-bound [31-33]. For magnet-controlled sorbent (MCS-B) both sorption and indirect effects are inherent, which are caused by the action of a constant magnetic field created by nanoparticles [34, 35]. The use of magnetite nanoparticles (MCS-B) will allow to approach the solution of existing problems in the correction of hemostatic systems and suppress aggregation of platelets in the optimal regime. Currently, there is no information in the literature on the study of the effect of nanoparticles on aggregation of platelets, there is 
no data on the development of an effective method of their application.

The above was the basis for choosing the topic of this study, devoted to the study of the influence of nanoparticles of magnet-controlled sorbent (MCS-B) on aggregation of platelets.

The main goal of the work is inhibition aggregation of platelets with using nanoparticles of magnet-controlled sorbent (MCS-B) in vitro experiment.

\section{Materials ANd Methods}

Materials: 1. Colloidal solution of magnetcontrolled sorbent (MCS-B). The basis of MCS$\mathrm{B}$ is magnetite nanoparticles $\left(\mathrm{Fe}_{3} \mathrm{O}_{4}\right)$. The size of nanoparticles is from 6 to $12 \mathrm{~nm}$; the total sorption surface magnetite of nanoparticles is from 800 to $1200 \mathrm{~m}^{2} / \mathrm{g}$; magnetization of saturation $I_{s}=2.15 \mathrm{kA} / \mathrm{m}$; volume concentration $\mathrm{q}=0.00448 ;$ viscosity $\eta=1.0112 \mathrm{cSt} ; \zeta$ potential $=-19 \mathrm{mV}$; saline $\mathrm{NaCl}$. Magnetite nanoparticles have been produced in Laboratory of Applied Nanotechnology of Belousov. Magnetite nanoparticles synthesized by coprecipitation method. The main physics and chemical properties of MCS-B the following data and also in Tables 1-4; Figures 1, 2 were presented:

- Concentration of the colloidal solution of magnetite nanoparticles in physiology solution of $\mathrm{NaCl}$ is $4.5 \%$.

- $\quad$ Size of magnetite nanoparticles is 6-12 nm;

- Total area of surface magnetite of nanoparticles $\mathrm{Ss}=800-1200 \mathrm{~m} 2 / \mathrm{g}$;

- Magnetization of saturation Is $=2.15 \mathrm{\kappa A} / \mathrm{m}$;

- $\quad \zeta$ - potential $=-19 \mathrm{mV}$.

2. $0.9 \% \mathrm{NaCl}$ solution.

Table1. The calculated lattice parameters of the phases.

\begin{tabular}{|l|l|l|l|l|l|l|}
\hline Phase name & $\mathrm{a}(\AA)$ & $\mathrm{b}(\AA)$ & $\mathrm{c}(\AA)$ & alpha (degree) & beta (degree) & gamma (degree) \\
\hline magnetite low & 8.387836 & 8.387836 & 8.387836 & 90.00 & 90.00 & 90.00 \\
\hline magnetite low, syn & 5.930687 & 5.930687 & 14.705912 & 90.00 & 90.00 & 120.00 \\
\hline Johannsenite & 9.891680 & 9.059276 & 5.282908 & 90.00 & 105.54 & 90.00 \\
\hline
\end{tabular}

Table2. Determination of percent composition of the ICNB by X-ray spectrometer ARL OPTIM'X (semiquantitative analysis).

\begin{tabular}{|l|l|l|l|l|l|l|l|l|}
\hline Compound & Weight $\%$ & StdErr & El & Weight\%/ $\mathrm{O}_{2}$ & StdErr & El & Weight\% & StdErr \\
\hline $\mathrm{Fe}_{3} \mathrm{O}_{4}$ & 97.37 & 0.09 & $\mathrm{Fe}$ & 68.40 & 0.07 & $\mathrm{Fe}$ & 97.62 & 0.09 \\
$\mathrm{CaO}$ & 2.26 & 0.07 & $\mathrm{Ca}$ & 1.71 & 0.05 & $\mathrm{Ca}$ & 2.3 & 0.07 \\
$\mathrm{P}_{2} \mathrm{O}_{5}$ & 0.280 & 0.027 & $\mathrm{Px}$ & 0.122 & 0.012 & $\mathrm{Px}$ & 0.157 & 0.015 \\
$\mathrm{MnO}$ & 0.255 & 0.013 & $\mathrm{Mn}$ & 0.198 & 0.010 & $\mathrm{Mn}$ & 0.278 & 0.014 \\
$\mathrm{SiO}_{2}$ & 0.098 & 0.027 & $\mathrm{Si}$ & 0.046 & 0.013 & $\mathrm{Si}$ & 0.059 & 0.016 \\
$\mathrm{SO}_{3}$ & 0.032 & 0.013 & $\mathrm{Sx}$ & 0.0126 & 0.0051 & $\mathrm{Sx}$ & 0.0164 & 0.0066 \\
$\mathrm{Cl}$ & 0.0280 & 0.0090 & $\mathrm{Cl}$ & 0.0280 & 0.0090 & $\mathrm{Cl}$ & 0.0380 & 0.012 \\
\hline
\end{tabular}

Table3. X-ray analysis of ICNB in X-ray diffractometer Rigaku Ultima IV (CuKa, K $\beta$ filter - Ni), one-coordinate DTeX semiconductor detector

\begin{tabular}{|c|c|c|c|}
\hline Phase & Formula & Space group & № Card Database ICDD \\
\hline magnetite low & $\mathrm{Fe}_{2} .886 \mathrm{O}_{4}$ & $227: \mathrm{Fd}-3 \mathrm{~m}$, choice-2 & 10861339 (ICDD) \\
\hline magnetite low, syn & $\mathrm{Fe}_{3} \mathrm{O}_{4}$ & $166: \mathrm{R}-3 \mathrm{~m}$, hexagonal & 10716766 (ICDD) \\
\hline Johannsenite & $\mathrm{Ca} \mathrm{Mn}+2 \mathrm{Si}_{2} \mathrm{O}_{6}$ & $15: \mathrm{C} 12 / \mathrm{c} 1$, unique-b,cell-1 & 380413 (ICDD) \\
\hline
\end{tabular}

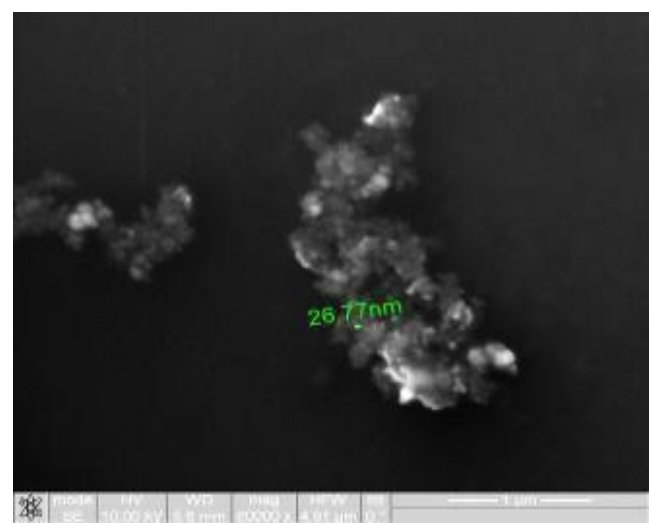

Fig1. Study of magnetite nanoparticles with use microscope ion-electronic raster-type Quanta $2003 \mathrm{D}$ 


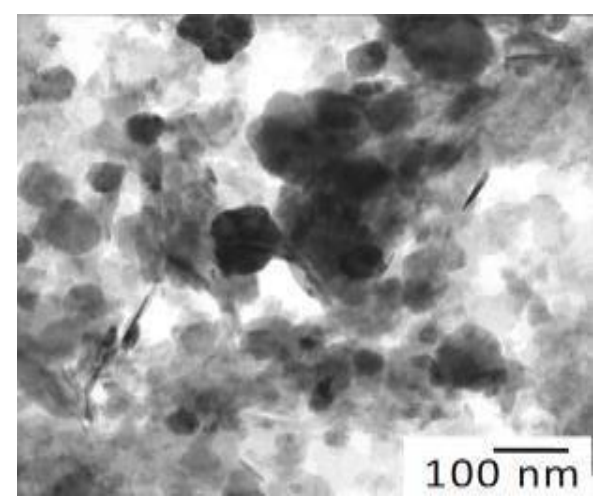

Fig2. Study of magnetite nanoparticles with use microscope electronic translucent JEM-2100

Table4. The phases of magnetite of nanoparticles (RIR - method; error $8 \pm 3 \%$ )

\begin{tabular}{l}
\hline Phases (method of corundum numbers) \\
\hline magnetite low \\
\hline magnetite low, syn (hexagonal) \\
Object of research: platelets in relatively healthy \\
volunteers. The number of volunteers was 14 \\
people. Under aseptic conditions, venous blood \\
in the amount of $16 \mathrm{ml}$ was taken from the ulnar \\
vein. Then the collected volume of blood in equal \\
parts ( $4 \mathrm{ml}$ ) was distributed to 4 heparinized test \\
tubes. Conditionally 4 test tubes were divided \\
into four experiments:
\end{tabular}

Experiment 1 were control tubes with venous blood;

Experiment 2 were tubes with venous blood +2 $\mathrm{ml}$ saline $\mathrm{NaCl}$;

Experiment 3 were tubes with venous blood +2 $\mathrm{ml} 4.5 \%$ colloidal solution of MCS-B;

Experiment 4 were tubes with venous blood +2 $\mathrm{ml} 4.5 \%$ colloidal solution of MCS-B with the subsequent removal of it from the blood by means Belousov's method.

The amount and concentration of MCS-B colloidal solution was used in accordance with the previously developed Belousov's method [20,
Content, \%

71

29

Quantitative determination aggregation of platelets activity by using aggregometer A-1 was carried out by the Bornov's method in the modification of Zachary and Kinah [36-39].

Statistically processing the obtained results was carried out by parametrical method of variation statistics by Student criterion. Processing the obtained data was carried out by means of Excel.

\section{RESULTS AND DisCUSSIONS}

To identify the main mechanisms of action of magnetite nanoparticles (MCS-B) on platelet aggregation parameters, different variants of blood processing by MCS-B were investigated. Taking into account the fact that a physiological solution was used as a carrier of MCS-B fluid, the effect influence of physiological solution of $\mathrm{NaCl}$ on platelet aggregation parameters were studied for the purity of the experiment. Platelet aggregation indicators depending on different variants of blood treatment with solutions are presented in table 5 . 22].

Table5. Influence of different variants of solutions for blood treatment on platelet aggregation $(n=14 ; M \pm m)$

\begin{tabular}{|c|c|c|c|c|}
\hline \multirow[b]{2}{*}{$\begin{array}{l}\text { Indicator of platelets } \\
\text { aggregations }\end{array}$} & \multicolumn{4}{|c|}{ Experiments, blood treatment options } \\
\hline & 1 & 2 (blood $+0.9 \% \mathrm{NaCl})$ & $\begin{array}{l}3 \\
(\text { blood + MCS-B) }\end{array}$ & $\begin{array}{l}4 \\
\text { (blood after removed } \\
\text { of MCS-B) }\end{array}$ \\
\hline $\begin{array}{l}\text { The rate of platelet } \\
\text { aggregation Optical- } \\
\text { density /min }\end{array}$ & $0.011 \pm 0.002$ & $\begin{array}{l}0.036 \pm 0.003 \\
\mathrm{p}_{1}<0.001\end{array}$ & $\begin{array}{l}0.0002 \pm 0.0001 \\
\mathrm{p}_{1}<0.001 \\
\mathrm{p}_{2}<0.001\end{array}$ & $\begin{array}{l}0.028 \pm 0.002 \mathrm{p}_{1}<0.001 \\
\mathrm{p}_{2}<0.05 \\
\mathrm{p}_{3}<0.001\end{array}$ \\
\hline $\begin{array}{l}\text { Index of platelet } \\
\text { aggregation, } \%\end{array}$ & $13.1 \pm 1.2$ & $\begin{array}{l}22.2 \pm 1.1 \\
\mathrm{p}_{1}<0.001\end{array}$ & $\begin{array}{l}0.7 \pm 0.1 \\
\mathrm{p}_{1}<0.001 \\
\mathrm{p}_{2}<0.001\end{array}$ & $\begin{array}{l}20.1 \pm 1.3 \\
\mathrm{p}_{1}<0.001 \\
\mathrm{p}_{2}>0.05 \\
\mathrm{p}_{3}<0.001\end{array}$ \\
\hline $\begin{array}{l}\text { Index of platelet } \\
\text { disaggregation, } \%\end{array}$ & $11.2 \pm 1.2$ & $\begin{array}{l}8.8 \pm 1.1 \\
p_{1}>0.05\end{array}$ & $\begin{array}{l}23.2 \pm 1.2 \\
\mathrm{p}_{1}<0.001 \\
\mathrm{p}_{2}<0.001\end{array}$ & $\begin{array}{l}13.8 \pm 1.1 \\
\mathrm{p}_{1}>0.05 \\
\mathrm{p}_{2}<0.01 \\
\mathrm{p}_{3}<0.001\end{array}$ \\
\hline
\end{tabular}

Notes: $p_{1}$-in comparison with the first experience (control); $p_{2}$-in comparison with the 2 nd experience (blood + $0.9 \% \mathrm{NaCl}$ ); $p_{3}$-in comparison with the $3 \mathrm{rd}$ experience (blood $\left.+\mathrm{MCS}-\mathrm{B}\right)$. 
The data of table 1 show that the use of $0.9 \%$ $\mathrm{NaCl}$ in comparison with the control, causes a significant $(\mathrm{P}<0.001)$ increase in speed by 0.025 optical density/min and platelet aggregation index by $9.1 \%$. At the same time, there was no significant decrease in platelet disaggregation index. In the third experiment, where venous blood was MCS-B, compared with the control significantly $(\mathrm{P}<0.001)$ marked a sharp decrease by 0.0108 optical density/min and platelet aggregation index by $12.4 \%$. Also increase in platelet disaggregation index was revealed significantly $(\mathrm{P}<0.001)$ by $12 \%$. In the fourth experiment, where the treatment of venous blood by MSC-B with followed by its removed, compared with the control, there was a significant $(\mathrm{P}<0.001)$ increase in rate by 0.017 optical density/min and platelet aggregation index by $7 \%$. Significant increase in platelet disaggregation wasn't observed. However, compared with the 2nd experiment, where $0.9 \%$ $\mathrm{NaCl}$ was added to the blood, an increase of platelet disaggregation index by $5 \% \quad(p<0.01)$ was reliably revealed. For clarity, the dynamics of platelet aggregation in different versions of the experiments is presented graphically in Fig. 3 .

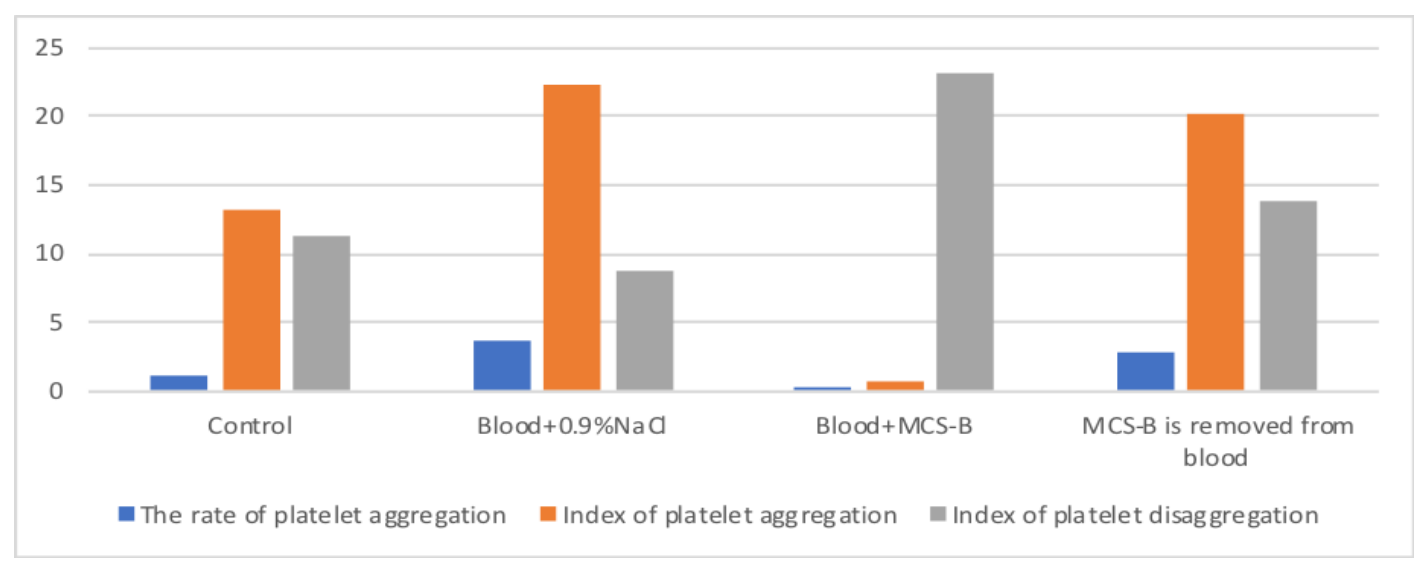

Fig3. Dynamic indicators of platelet aggregation $(n=14)$.

Comparative analysis of the results of the 3rd and 4th experiments showed that the main reason of the differences effects that were obtained is associated with different methods of applications of MCS-B. In the third experiment, the MCS-B nanoparticles were not removed from the blood. Since MCS-B nanoparticles have sorption activity, a certain amount of them is sorbed on the surface of protein structures of platelet membranes. The constant magnetic field that induced by MCS-B nanoparticles (300-400 $\mathrm{kA} / \mathrm{m}$ ) changes not only the bioelectric charge of platelet membranes [40], but also affects intracellular biochemical processes, activity of enzyme systems. Ultimately this caused activation of disaggregation, decreased of rate and platelet aggregation index in the third experiment. The data of I. M. Movshovich and M. A. Shilo confirm the above. The constant magnetic field slows down ESR and improves microcirculation. This is associated with disaggregating effect of magnetic field, decrease in viscosity and hemostatic potential of blood with improvement of its rheological properties [41]. N. F. Lezhenina and V. N. Rodionov also note that the use of magnetic hemotherapy in combination with hemosorption allows to reduce the dose of anticoagulants [42].
Reasoning about the mechanism of the effects obtained it should be said that the magnetic field can cause synchronization of initially weak oscillations of several groups of cells (trigger reaction), which is confirmed by scientific works of a number of authors [41, 43, 44]. Such inphase oscillations can be as an information signal for various regulatory systems of the body, which leads to various macroscopic effects in the form of conformational restructuring of cellular structures. Self-oscillations, probably occurring in the blood cell membranes, when the vibrational part of the membrane begins to act as a pump, have a significant impact on the ionic and molecular transport of substances through the cell membrane.

The magnetic field affects the processes of lipid peroxidation and redox processes, elements of cell structures, protein-enzyme molecules having a dipole moment [45]. Adding to the list of mechanisms of influence of magnetic fields on biological processes, it should be noted the process of structuring water with a change in the orientation of the nuclear spins of hydrogen in its molecule, which probably also affects the course of enzymatic processes [46, 47]. 
Thus, the effect of predominance of magnetic properties of MCS-B nanoparticles over sorption ones was observed in the third experiment. MCS$B$ nanoparticles increase the negative charge of the membrane, which leads to a decrease in their aggregation.

In contrast in the fourth experiment where MCS$\mathrm{B}$ was extracted from venous blood using a constant magnetic field (20-25 mT) the sorption properties of the nanoparticles prevailed over the magnetic ones [20]. The mechanism of action of MCS-B was primarily associated with the effect of sorption of surface proteins of blood cell membranes [22]. The result of the above effect is a reliable decrease in the platelet aggregation rate $(\mathrm{P}<0.05)$ and an increase in the platelet disaggregation index $(\mathrm{P}<0.01)$ compared to the experiment in which $0.9 \% \mathrm{NaCl}$ was used.

\section{SuMmary}

The results of the study showed that the use of $\mathrm{NaCl}$ saline solution in conditions of severe disturbances of blood microcirculation and rheology in order to improve them is not only doubtful, but also unsafe. In this case, the colloidal suspension equilibrium of platelets is shifted towards a significant $(\mathrm{P}<0.001)$ increase in the rate and index of their aggregation. On the contrary, the use of MCS-B nanoparticles significantly $(\mathrm{P}<0.05)$ revealed an increase in the stability of colloidal suspension of blood cells (platelets), which in conditions of impaired microcirculation and rheology of blood is an important pathogenetic factor for the occurrence of sanogenetic effects. In the case of correction of the platelet link of the blood coagulation system, blood treatment by MCS-B nanoparticles is preferable to the introduction of $0.9 \% \mathrm{NaCl}$. First of all, this is probably due to the restoration of the Zeta potential of platelets [20].

\section{CONCLUSIONS}

1. In the experiment aggregation of platelets was suppressed with means extracorporeally by using nanoparticles of magnet-controlled sorbent (MCS-B).

2. The presence of MCS-B nanoparticles in the blood, compared with the control, significantly $(\mathrm{P}<0.001)$ reduces by 0.0108 optical density/min index and platelet aggregation index by $12.4 \%$. At the same time of the platelet disaggregation index has been increased significantly $(\mathrm{P}<0.001)$ by $12 \%$.
3. Treatment of venous blood by MCS-B with its subsequent removed significantly $(\mathrm{P}<0.001)$ increases aggregation rate by 0.017 optical density/min and platelet aggregation index by $7 \%$ compared with the control. Compared with $0.9 \% \mathrm{NaCl}$ the use of MCS-B nanoparticles, the platelet disaggregation index significantly increased $(\mathrm{P}<0.01)$ by $5 \%$.

4. The use of $0.9 \% \mathrm{NaCl}$ in comparison with the control causes a significant $(\mathrm{p}<0.001)$ increased in aggregation speed by 0.025 optical density/min and platelet aggregation index by $9.1 \%$. At the same time, there was no significant decrease in the platelet disaggregation index.

\section{REFERENCES}

[1] Luzhnikov E. A. Clinical toxicology. - M.: Medicine, 1982. - 368 p.

[2] Zayko N. N., Bits Yu. V., Ataman A. V. et al. Pathological physiology of the blood system. In the book.: Pathological physiology. K.: "Logos", 1996. - P. 125-130.

[3] Fundamentals of human physiology / Edited by B. I. Tkachenko - St. Petersburg: International foundation for the history of science, 1994. V.1.- $566 \mathrm{p}$.

[4] Holodov Yu.A. Magnetism in biology. - M.: The science, 1970. - $96 \mathrm{p}$.

[5] Zenkov N.Z., Marcheko Yu.Yu., Tofimov A.V. The role of radical processes in the magnetosensitivity of the human body // In the book: Magnetic fields in biology, medicine and agriculture / Abstracts of II Region of Science. Center for new information technologies. Rostov-on-Don, 1985. - P. 20-21.

[6] Ponomarenko G.N. Electromagnetometry and phototherapy. - SPb.: Peace and family, 1995. P. 159-166.

[7] Jancovich B.D., Goldfarb Ju.S., Misulovin Ja.I. et al Magnetic hemotherapy as an effective resuscitation technique for treatment of acurte axogenic poisoning // Curr. Toxicol. - 1993. Vol. 1. - №2. - P. 133-139 (USA).

[8] Lopuhin Yu. M., Molodenkov M. I. Hemosorption. - M.: Medicine, 1982. - 368 p.

[9] Versin A. A. Magnetotherapy in ophthalmology // In the book: Electromagnetic fields in the biosphere. - M., 2001. - P. 65.

[10] Mitbreit I. M., Savchenko A. G., Medvedovsky N. N. Application of "running" pulsed lowfrequency magnetic field in the treatment of patients with dystrophic diseases of the spine and joints. // In the book: Magnetic fields in biology, medicine and agriculture / Abstracts of the 2nd Scientific-Practical Conference-Rostovon-don, 1985. - P. 91-93. 
[11] Surganova S. F. Magnetotherapeutic correction of ischemic disorders in extremities // In the book: Magnetic fields in biology, medicine and agriculture / Abstracts of the 2nd ScientificPractical Conference. - Rostov-on-Don, 1985. P.127-128.

[12] Smelova V. I., Taran N. A., Levit L. A. application of magnetotherapy in complex treatment of gynecological patients // In the book: Magnetic fields in biology, medicine and agriculture / Abstracts of the 2nd ScientificPractical Conference. - Rostov-on-Don, 1985. P.196-198.

[13] Orlov L. L., Mikhailov, S. D., Matt N.O. The action of an impulse magnetic field in hypertension // Soviet medicine. - 1987. - No. 2. - P. 19-21.

[14] Kholodov Yu. A. Magnetism in biology. Moscow: Nauka, 1970. - 96 p.

[15] Novoselov V. P., Nikitina T. V., Kozyrev O. I., Dilis A.D. some features of the influence of changes in Helio-geophysical factors on sudden death from coronary heart disease. // In the book: Magnetic fields in biology, medicine and agriculture / Abstracts of the 2nd ScientificPractical Conference. - Rostov-on-Don, 1985. P.122-123.

[16] Gvazava E.A. Evaluation of mutagenic activity of magnetic fluid of biological significance // Abstracts of II Conferences " On the application of magnetic fluids in biology and medicine ". Sukhumi, 1985. - P. 7-8.

[17] Frank V.A. The use of magnetically sensitive ointments in purulent surgery // 5th All-Union meeting on the physics of magnetic fluids. Perm, 1990. - P. 115-116.

[18] Ahalaya M.G., Zakaraya K.A., Какиаshvily M.S. et al. Obtaining and physical-chemical properties of magnetic fluids for biomedical applications. // Materials of the 3rd All-Union school-seminar on magnetic liquids.- M.: MSU, 1983. - P. 11-12.

[19] Permichev A.N., Cybusov S.N., Bulanov G.A. Magnetically controlled hemosorption // Abstracts of 7th international Pless conference on magnetic fluids. Application in biology and medicine. - Pless, 1996. - P. 124-125.

[20] Belousov A.N. Extracorporeal hemocorrection using magnetically controlled sorbent in intensive therapy of intoxication syndrome in patients with pathology of hepatopancreatoduodenal zone: Abstract of the dissertation for the degree of DM: 14.01.30 / DSMA-Dnepropetrovsk, 2004. - 40 p.

[21] Belousov A.N. Sorbent for extracorporeal detoxification of biological liquids: State Patent No. 24322A UA A61N2/00 / Publ. 17.07.98. Bull. No. 7. - 4 p.
[22] Belousov A.N. Method of extracorporeal detoxification of biological fluids: State Patent No. 24183A UA A61N2/00 / Publ. 17.07.98. Bull. No. 7. - 3 p.

[23] Belousov A.N. Method of production of a magnetic liquid for transport and retention of medicines in organism Patent of Ukraine №14817A UA A61N2/00 / № 96062463. Decl. 21.06.96; Publ. 18.02.97.

[24] Belousov A.N. Therapeutic and prophylactic product "Micromage-B". State patent No. 30538A UA A 23L 1/304 No. 98052704 Decl. 25.05.98. Publ. 15.11.00. Bull. No. 6-11.

[25] Belousov A.N. The use of magnetite nanoparticles in applied medicine. International Journal of Nano Dimension. Vol.2. Issue 1(5). Summer 2011. P.25-28. Print Edition ISSN: 2008-8868. Web Edition ISSN: 2228-5059

[26] Belousov A.N., Belousova E.Yu. The first steps in discovery new mechanisms of cellular regulation in means by nanotechnology preparations // X International Conference New Information Technologies in Medicine and Ecology. - Yalta, Gursuf, 2002. - P.420-425.

[27] Belousov A.N., Belousova E.Yu. Mechanisms cell regulation by nanotechnology preparations (MCS-B). BioNanotech Conference \& Expo 2012. June 18-21, 2012, Santa Clura, CA, USA.

[28] Belousov A.N. Effect of magnet controlled sorbent on parameters of acid-base balance of the blood and the processes of glycolysis in erythrocytes. Pain, anesthesia and intensive care. - Kiev. - 2000. - № 1. P. 263-265.

[29] Belousov A.N., Nevzorov V.P. Ultrastructure of cells in the kidneys and lungs of rabbits after administration of magnetite // International collection of scientific papers IV Scientific and Practical Conference on the Creation and Testing of New Drugs. - Moscow, 1997. V.4. P. 77-87.

[30] Belousov A.N., Nevzorov V.P. Ultrastructure of liver cells after administration of magnetite // International collection of scientific papers IV Scientific and Practical Conference on the Creation and Testing of New Drugs. - Moscow, 1997, V.4. - P. 71-77.

[31] Belousov A.N. Spectrum of Application Magnetite Nanopaticles in Medicine. Nanotech 2009. Vol. 2 Chapter 3, pp.154 - 157. - ISBN: 978-1-4398-1783-4

[32] Belousov A.N. Effect on hemolysis and transport ATPase activity of erythrocytes by means nanopareticles of magnetit controlled sorbent (MCS-B). Pain, anesthesia and intensive care. - Kiev. - 2012. - № 1 (ad). P.26-28.

[33] Belousov A.N. Ultrastructure of Hepatic Cells after Intravenous Injection of Magnetite Nanoparticles ICNB. J. Cell Mol. Biol. 2017. Henry Publishing Group. Volume: 2. Issue:1. 100004 ISSN: HJCM P.1-4. 
[34] Belousov A.N. Nanotechnology and Discovery of a New Factor Which Influences on Permeability of Erythrocytes and Eryptosis. Journal of Materials Science and Engineering A 4 (11) (2014). P. 367-372 ISSN 1934-8959, USA.

[35] Belousov A., Voyda Yu, Belousova E. Influence of Physical Factors Caused by Magnetite Nanoparticles on Different Groups of Microorganisms. Journal of Nanotechnology and Materials Science. USA, 2015. Vol.2.Issue 2. PP.1-4. ISSN: 2377-1372

[36] Order of the Ministry of health of the USSR No. 960 of 15.10 .74 "on unification of clinical and laboratory research methods". A simplified means of determining platelet AG-regulation and disaggregation by born in the modification of Zachary, Kinah.

[37] Berkovsky A. L., Vasiliev S. A., Zherdeva L. V. et al. Manual on the increase of adhesiveaggregation activity of platelets. M., 2002, 28 p.

[38] Severina I. S., Busygina O. G., pyatakova N. V. activation of soluble GU-anilate cyclase by new NO donors as a basis for directed search for new effective vasodilators and antiplatelets. // Bulletin of the Russian Academy of medical Sciences - 2000. - V. 4. - P. 25-30.

[39] Chirkov Yu. Yu., Belushkina N. N., Tyschuk I. A., Severina I. S. The Role of guanylate cyclase in the regulation of human platelet aggregation / Bulletin of the USSR Academy of medical Sciences.-1991.- V. 10.- P. 51-55.

[40] Belousov A. N. Influence of a new method of extracorporeal hemocorrection with the use of a magnetically controlled sorbent on the blood circulation system in patients with intoxication syndrome. // Medicine today and tomorrow,
Kharkiv state medical University, 2000. - No. 1. P. 85-89.

[41] Movshovich I. M., Shilo M. A. On the effect of MF on biological systems. In the book: Proceedings of the 2nd All-Union meeting on the study of the influence of magnetic fields on biological objects. - M., 1969. P. 155-158.

[42] Lezhenina N. F., Rodionov V. N. The method of clinical toxometry in assessing the effectiveness of treatment of toxic encephalopathy in the somatogenic phase of acute poisoning. In the book: Theoretical and clinical issues of modern reanimatology progress. / Proceedings of the international Symposium. - M., 1999. - P. 88.

[43] Klassen V. I. On the influence of weak magnetic fields on water systems. In the book: Reaction of biological systems to weak magnetic fields. / Proceedings of the All-Union Symposium. - M., 1971. - P. 14-16.

[44] Kovalchuk A.V. On some mechanisms of action of PMF on biological objects. In the book: Reaction of biological systems to weak magnetic fields. / Proceedings of the All-Union Symposium. - M., 1971. - P. 29-33.

[45] Luzhnikov E. A., Goldfarb Y. S. Physiohemotherapy of acute poisoning. M.: Medpraktika. - M.-2002. - 199 p.

[46] Piccardi G. L'influence des phenomenes terretres, solaires et cosmiques sur les reactions phisico-chimiques et biologiques. - Bruxelles. 1956. - 123 p.

[47] Straub K.D., Carver P. Effects of electromagnetic fields on microsomal ATPase and mitochondrial oxidative phosphorylation. // Ann. N.Y. Acad. Sci. - 1975. - Vol.6. - P.247254.

Citation: Andrey N. Belousov. Study of the Effect of Nanotechnology Drugs (MCS-B) on the Aggregation of Human Blood Platelets ARC Journal of Anesthesiology. 2019; 4(2): 11-18. doi:dx.doi.org/ 10.20431/24559792.0402003.

Copyright: () 2019 Authors. This is an open-access article distributed under the terms of the Creative Commons Attribution License, which permits unrestricted use, distribution, and reproduction in any medium, provided the original author and source are credited. 